Int. J. Electrochem. Sci., 12 (2017) $9652-9664$

\title{
Effect of Streptococcus mutans on the Corrosion Behavior of Nano-Coating Ni-Cr Dental Alloy
}

\author{
M.A. Ameer ${ }^{1, *}$, A.M. Fekry ${ }^{1}$ and, May M.A. Bahr ${ }^{2}$ \\ ${ }^{1}$ Chemistry Department, Faculty of Science,CairoUniversity,Giza12613,Egypt \\ ${ }^{2}$ National Research Center, 33El Bohouth St.P.O.12311, Egypt \\ *E-mail: mameer_eg@yahoo.com,
}

doi: $10.20964 / 2017.10 .33$

Received: 19 May 2017 / Accepted: 28 July 2017 / Published: 12 September 2017

Corrosion behavior of chitosan, hydroxyapatite and $\mathrm{TiO}_{2}$ nanoparticles $\left(\mathrm{CS} / \mathrm{TiO}_{2} / \mathrm{HA}\right)$ nano- layer Ni$\mathrm{Cr}$ (Wirolloy) casting dental alloy and unlayerd one were studied with time after exposing the tested alloys to fluoridated artificial saliva media without and/or with streptococcus mutans (S.mutans) Techniques used for corrosion examination were electrochemical impedance spectroscopy (EIS) and potentiodynamic techniques. SEM and EDX analysis was studied to characterize the layerd film in absence or presence of bacteria. All measurements indicated that $\mathrm{CS} / \mathrm{TiO}_{2} / \mathrm{HA}$ nano-coatingr has high antibacterial effectiveness. Surface coverage increases with immersion time reaching a constant value after $72 \mathrm{~h}$ and it was found to be 0.987 and 0.925 for $\mathrm{CS} / \mathrm{TiO}_{2} / \mathrm{HA}$ Nano-coatingr calculated from EIS and potentiodynamic techniques, respectively, after 6 days in presence of bacteria indicating the inactive property of the layer.

Keywords: Streptococcus mutans ; Chitosan; $\mathrm{TiO}_{2}$; Hydroxyapatite; Wirolloy.

\section{$\underline{\text { FULL TEXT }}$}

(C) 2017 The Authors. Published by ESG (www.electrochemsci.org). This article is an open access article distributed under the terms and conditions of the Creative Commons Attribution license (http://creativecommons.org/licenses/by/4.0/). 